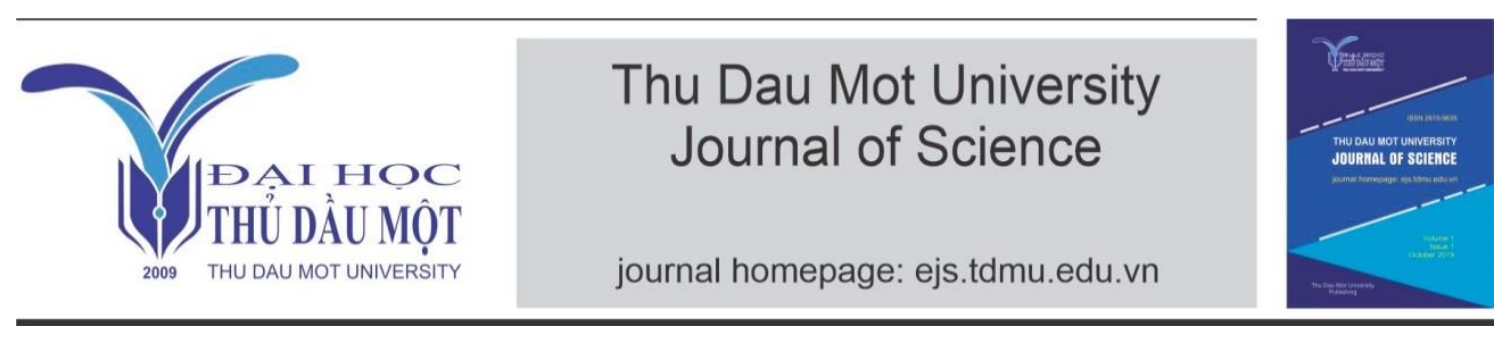

\title{
Investigation of Grid-connected PV System with Electrical Appliances, Electric Vehicles
}

\author{
by Nguyen Ba Thanh (Thu Dau Mot University)
}

\begin{abstract}
Article Info: Received 15 Mar. 2021, Accepted 2 June 2021, Available online 15 June 2021
Corresponding author: thanhnb@tdmu.edu.vn

https://doi.org/10.37550/tdmu.EJS/2021.02.197
\end{abstract}

\begin{abstract}
Electric vehicles (EVs) making a significant contribution to the reduction of fossil fuel consumption and CO2 emissions are expected to thrive in Vietnam in the upcoming years/in the near future. However, such vehicles' energy demand could become a burden on the transmission networks, causing overloads to the electric grid of the nation. Hence, to solve this problem, a solar PV system can be utilized to fulfill the electricity needs in an EV charging station. This article presents the design, simulation and economic analysis of a grid-connected solar power system for an electric charging station at Thu Dau Mot University (TDMU). The photovoltaic (PV) power system is designed to supply energy to the charging station and office building. The study estimates the generated electricity, the efficiency of the PV power system and the ability to reduce CO2 emissions. This paper can be a recommended input for stakeholders to consider using this energy source for charging vehicles.
\end{abstract}

Keywords: on-grid rooftop PV, solar PV system, PV*SOL, photovoltaic system, electrical vehicles, charging station

\section{Introduction}

Vietnam is a country with high economic growth, with an annual gross domestic product (GDP) of about 7\% over the past decade (IMF., 2019; Kimura et al., 2019). With a dynamic economy and high energy demand, however, in the field of energy, Vietnam still has to depend mainly on hydropower and thermal power from fossil fuels 
(Nong et al., 2020). Vietnam has great potential for solar radiation, with an average radiation intensity of $5 \mathrm{kWh} / \mathrm{m} 2$ (Polo et al., 2015). However, the use of solar power in Vietnam has progressed slowly in recent years. Solar power had not been considered a viable power generation option until 2015 when Vietnam's Renewable Energy Development Strategy was enacted (Government of Vietnam, 2015). Besides, the Prime Minister issued Decision on the mechanism for the development of solar power in Vietnam (The Prime Minister, 2017). In addition, Vietnam is currently facing many serious environmental problems such as air pollution, water pollution, land degradation, etc. mainly due to industrial production and transportation. As a result, electric cars will be one of the most promising means of transport that helps reduce environmental pollution and energy pressure in Vietnam (Bellekom et al., 2012).

Currently, electric vehicle technology is developing rapidly and will completely replace traditional vehicles in the future. Electric vehicles use an electric motor instead of an internal combustion engine, powered by a rechargeable lithium-ion battery. For convenience of mobility, electric vehicles need charging stations such as gas stations of gasoline engines (Salah et al., 2019; Larcher \&. Tarascon, 2015). With the development of photovoltaic technology, the price of solar power is decreasing, thereby increasing the feasibility of solar projects (Green, 2019). There are many domestic and foreign authors who have studied the power supply for EV charging stations:

Nguyễn (2017) researched an EV charging station in Da Nang city. The thesis calculated and designed a solar energy system used for an EV charging station and evaluated the ability to charge electric vehicle's battery. PV*SOL Premium 2017 software was adopted to design, calculate and simulate the operation of electric vehicle charging stations.

Chandra Mouli et al. (2016) designed a 10kW solar power system for an electric vehicle charging station.

Domínguez-Navarro et al. (2018) designed an electric vehicle fast charging station that integrates renewable energy and storage systems.

Karmaker et al. (2018) designed and economically evaluated a solar and biogas renewable energy charging station project by using HOMER software. The proposed electric vehicle charging station is an integration system of a solar PV module (10kW), three biogas generators $(10 \mathrm{~kW}), 25$ lead acid batteries (each 100Ah), a converter $(10 \mathrm{~kW})$ and charging assemblies. This configuration estimated a Cost of Energy (COE) of $\$ 0.1302 / \mathrm{kWh}$, total net present cost (NPC) of $\$ 56,202$ and operating cost of $\$ 2,540$. In addition, the proposed model reduced the $\mathrm{CO} 2$ emissions by $34.68 \%$ compared to a conventional grid-based charging station.

Ekren et al. (2021) designed a wind-solar hybrid charging station system by using HOMER software. The optimal solution for the hybrid system consists of $44.4 \%$ wind 
energy and $55.6 \%$ solar energy and the annual electricity production is $843,150 \mathrm{kWh}$ with the $\$ 0.064 / \mathrm{kWh}$ production cost.

Pushpavalli et al. (2021) have evaluated the economic and technical aspects of the solar power system for electrical appliances, EVs and battery systems by using PVSOL software.

Rooftop solar power has been strongly developed in recent years (Le Nguyen et al., 2019), but there are no adequate studies for the setting up of electric vehicle charging stations in weather conditions in Vietnam (Nguyen et al., 2020). In this study, the proposed grid-connected rooftop solar power system for electric vehicle charging station at Thu Dau Mot University is presented. The main purposes of the research are:

- Designing a rooftop solar power system for an EV charging station;

- Evaluating efficiency and the amount of $\mathrm{CO}_{2}$ saved emissions of the solar power system by using the PVSOL software;

- Evaluating economic feasibility of the project.

\section{Materials and Methods}

This study is conducted with the steps shown in Figure 1. First, the solar power system is designed and equipment is selected to meet the actual load demand. Next, the solar power system is simulated by the PVSOL software (Software , 2021) to evaluate energy efficiency. Finally, economic feasibility of the project is calculated.

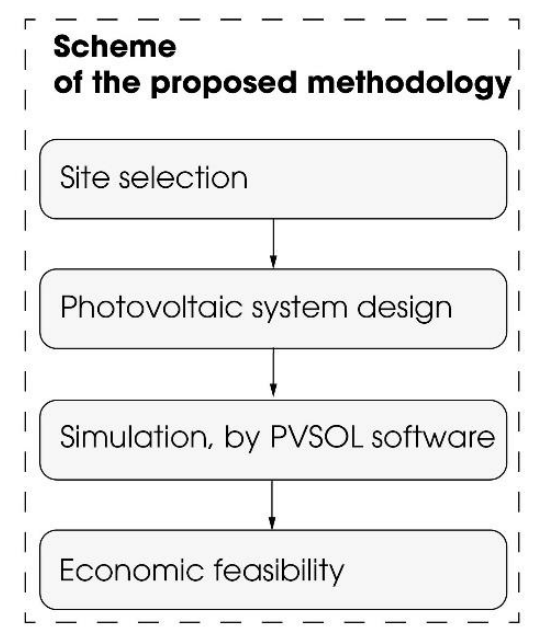

Figure 1. General scheme of the proposed methodology used in the study

\subsection{Brief summary of electric vehicles and charging stations}

\subsubsection{Types of electric vehicles}

EVs can be divided into two main categories (Das et al., 2020) hybrid electric vehicles (HEVs) and all-electric vehicles (AEVs). While each has advantages and disadvantages, 
they all save on fuel and emit fewer greenhouse gas than vehicles that burn fossil fuels only. They also recharge their batteries through regenerative braking. In this process, the vehicle's electric motor assists in slowing the vehicle and recovers some of the energy normally converted to heat by the brakes.

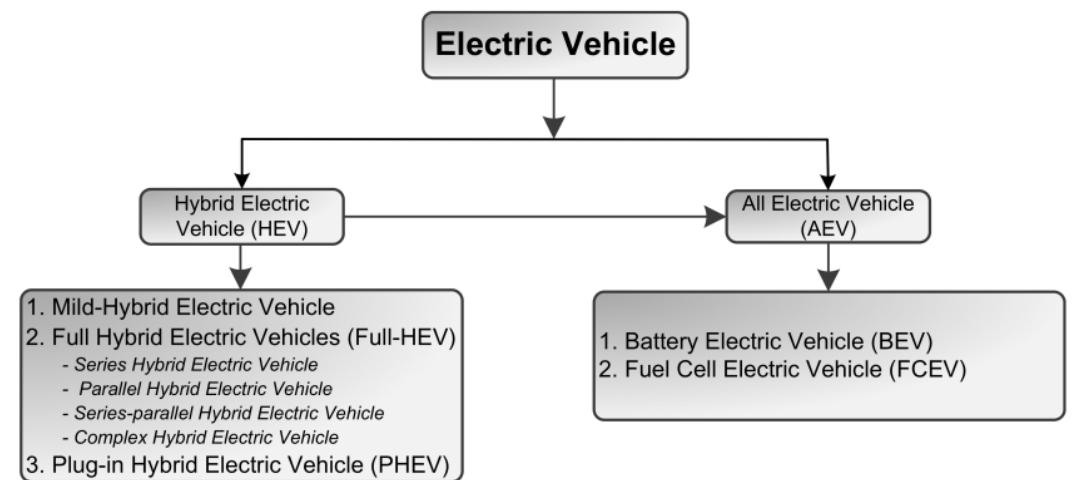

Figure 2. Basic types of electric vehicles (Tie \& Tan, 2013)

Figure 2 describes the classification of different types of EVs. In Table 1 below, the technical specifications of commercially available EVs released by different manufacturers are presented. The approximate charging time required to charge the vehicle from $0 \%$ to at least $80 \%$ in different charging standards are also shown in the table. Here, Level 1 corresponds to the charging voltage of $110-120 \mathrm{~V}$, Level 2 is of $220-240 \mathrm{~V}$ and Level 3 or DC fast charging (DCFC) is of 200-800 V. It should be noticed that the range of an EV based on battery drive is about $100 \mathrm{~km}$ for most of the vehicles, however, several models have the battery-drive ranges around $200 \mathrm{~km}-400 \mathrm{~km}$ (Das et al., 2020).

AEVs are equipped with only electric motors powered by electrical sources. AEVs can be further classified into Battery EVs (BEVs) and Fuel Cell EVs (FCEVs). A FCEV does not require an external charging system. However, a BEV relies only on external power from the grid for charging the storage unit. A plug-in hybrid EV (PHEV) is one type of HEVs with an option to recharge its battery from the grid (Tie \& Tan, 2013).

TABLE 1. Popular commercially available EV and its specifications (Das et al., 2020).

\begin{tabular}{|c|c|c|c|c|c|c|c|c|}
\hline \multirow[t]{2}{*}{$\begin{array}{l}\text { Vehicle } \\
\text { model }\end{array}$} & \multirow[t]{2}{*}{$\begin{array}{l}\text { Manufactur } \\
\text { er }\end{array}$} & \multirow[t]{2}{*}{$\begin{array}{l}\text { Model } \\
\text { Year }\end{array}$} & \multirow[t]{2}{*}{ Type } & \multirow{2}{*}{$\begin{array}{l}\text { Battery } \\
\text { Capacit } \\
\text { y (kWh) }\end{array}$} & \multirow[t]{2}{*}{$\begin{array}{l}\text { Range } \\
(\mathrm{km})\end{array}$} & \multicolumn{3}{|c|}{$\begin{array}{l}\text { Charging Time }(0 \%-80 \%) \\
(\mathrm{h})\end{array}$} \\
\hline & & & & & & $\begin{array}{l}\text { Level } \\
1\end{array}$ & $\begin{array}{l}\text { Level } \\
2\end{array}$ & DCFC \\
\hline $\begin{array}{l}\text { Prius } \\
\text { Prime }\end{array}$ & Toyota & 2018 & PHEV & 8.8 & $\begin{array}{l}40 \\
\text { (battery) }\end{array}$ & 5.5 & 2.1 & - \\
\hline Fit & Honda & 2014 & $\mathrm{BEV}$ & 20 & 132 & 15 & 3 & - \\
\hline Model S & Tesla & 2018 & $\mathrm{BEV}$ & 100 & 506 & 96.7 & 10.7 & 1.33 \\
\hline Focus & Ford & 2016 & $\mathrm{BEV}$ & 23 & 161 & 20 & 3.5 & 0.5 \\
\hline i3 & BMW & 2018 & $\begin{array}{l}\text { BEV and } \\
\text { PHEV }\end{array}$ & 33 & $\begin{array}{l}183 \\
\text { (battery) }\end{array}$ & $13-16$ & 5 & 0.5 \\
\hline
\end{tabular}

2.1.2 Architecture of the charging station 
EV charging is defined by the standards in (IEC., 2014). The charging plug type widely used in Europe for AC charging is the Type 2 Mennekes plug. It supports both single and three-phase AC charging at Level 2 charging power level (Chandra et al., 2016).

In this paper, a $12 \mathrm{kWp}$ on-grid PV system providing energy for cars will be considered and shown in Figure 3 below. Since the cars are parked for long durations of 6-10 hours at the workplace, fast charging would be unnecessary.

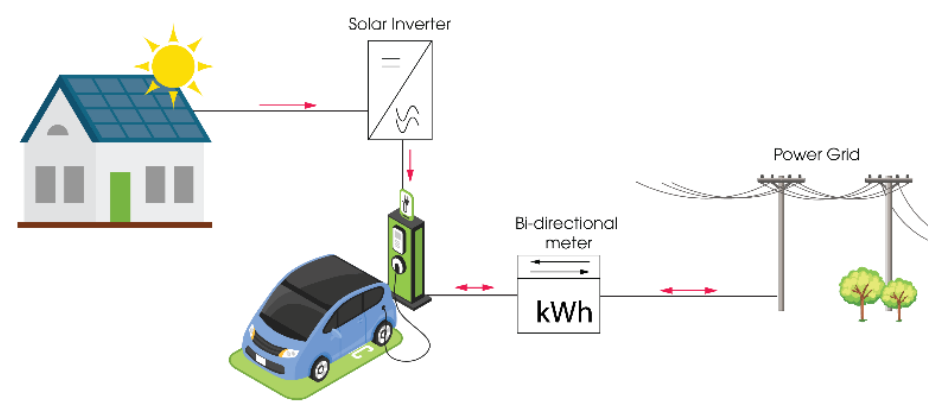

Figure 3. Diagram of on-grid photovoltaic system for the EV charging station

\subsection{Design of the proposed on-grid photovoltaic system}

In this study, the $12 \mathrm{kWp}$ solar power system is located on the roof of the E1 building (TDMU) and the charging station (as shown in Figure 4). This solar power system supplies the power to the charging station and the office building.

The electricity generated from PV power plants during the day can be charged directly to the electric vehicle. If the amount of electricity generated exceeds the demand of the vehicle, the excess energy can be sold to the grid via a two-way meter. In contrast, at night, the office area and the charging station get electricity from the national system through the two-way meter.

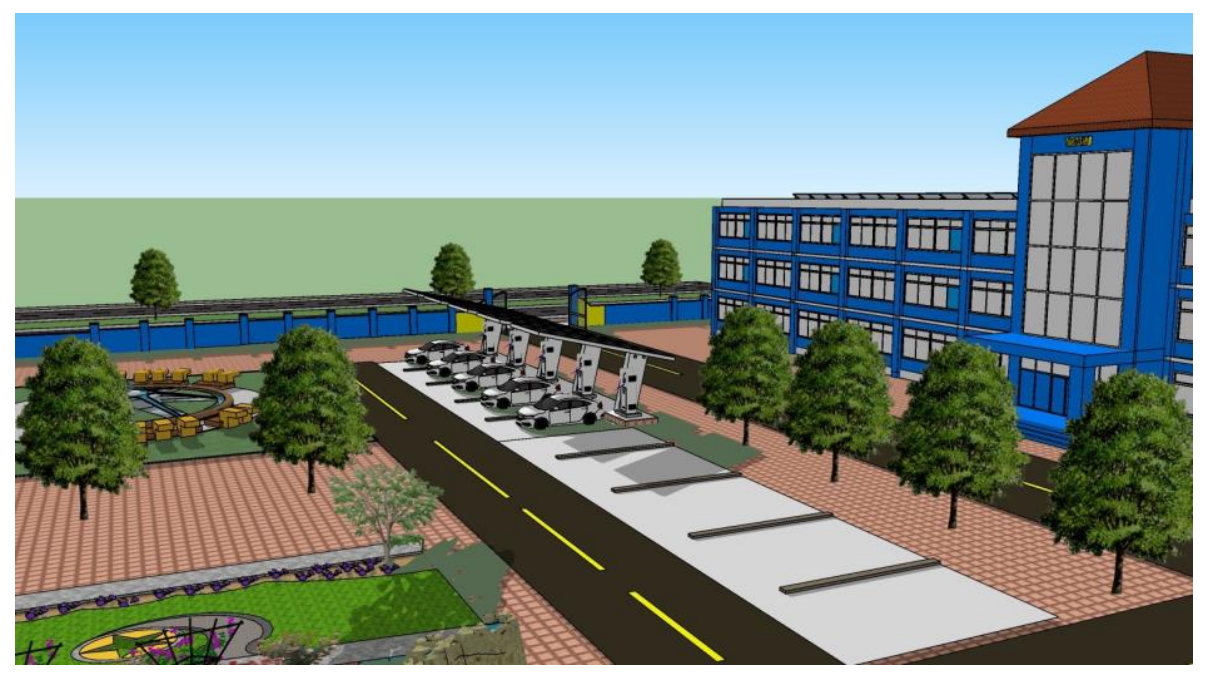

Figure 4. The proposed solar power system for the EV charging station at TDMU 
The process of designing a rooftop solar power system includes the following steps:

Step 1: Surveying the construction;

Step 2: Calculating the demand;

Step 3: Calculating the capacity of the solar PV arrays;

Step 4: Selecting inverter and related devices;

Step 5: Pre-feasibility assessment.

The building has the geographical location and weather parameters shown in Table 2 and Figure 5.

$T A B L E$ 2. Geographical location and weather parameters

\begin{tabular}{ll}
\hline Parameter & Value \\
\hline Longitude & $10^{\circ} 58^{\prime} 48.6^{\prime \prime N}$ \\
Latitude & $106^{\circ} 40^{\prime} 31.4^{\prime \prime} \mathrm{E}$ \\
Height & $29 \mathrm{~m}$ \\
Hours of sunshine & $4.58 \mathrm{~h}$ \\
Radiation intensity & $3.915(\mathrm{kWh} /$ day $/ \mathrm{m} 2)$ \\
Wind speed & $2.3 \mathrm{~m} / \mathrm{s}$ \\
\hline
\end{tabular}

\section{Horizontal solar radiation $(\mathrm{kWh} / \mathrm{m} 2$}

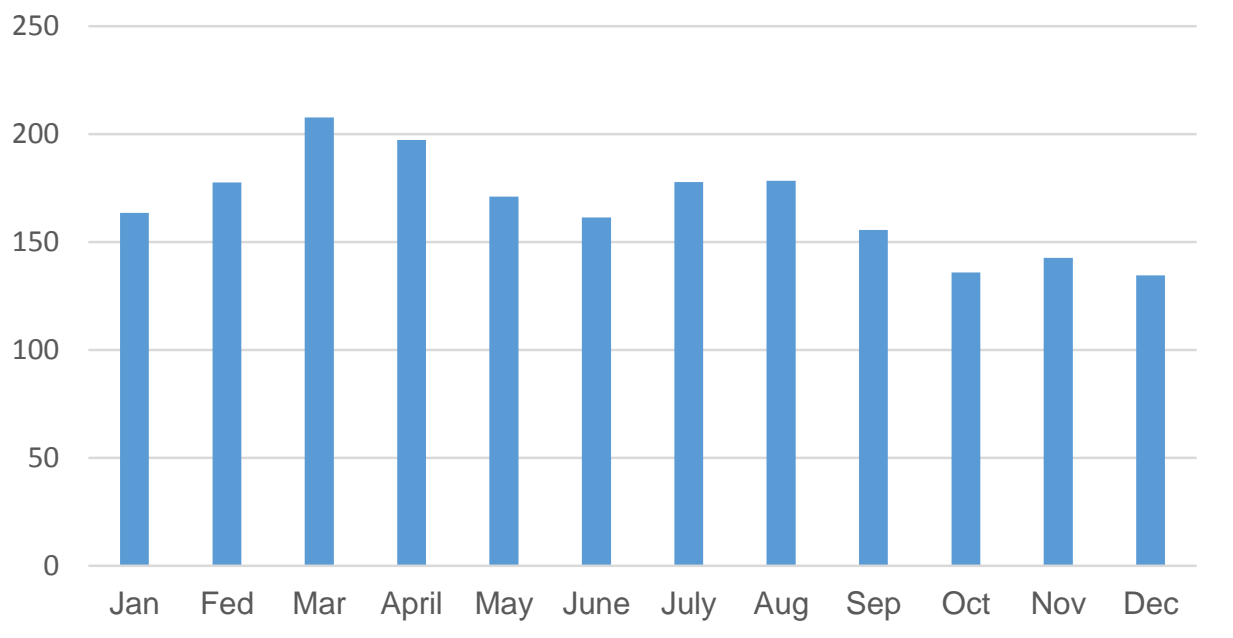

Figure 5. Monthly solar radiation intensity

The electrical demand of the office building is depicted in Figure 6. The electric vehicle charging station can charge five vehicles at the same time, the typical parameters of the vehicle are described in Table 3. 


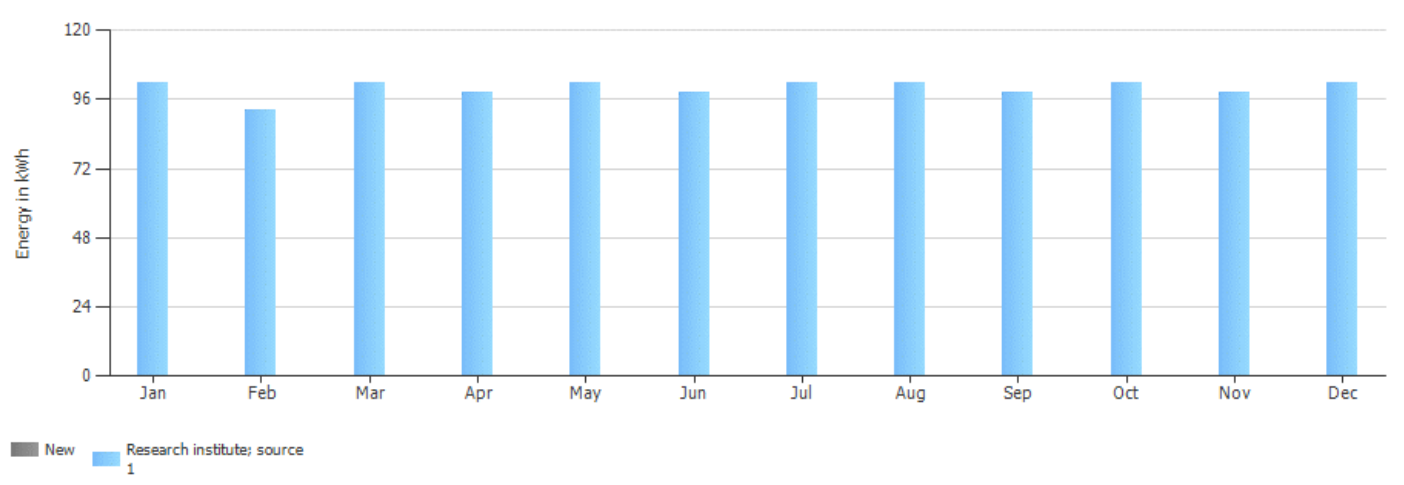

Figure 6. Monthly electrical demand of the office building

TABLE 3. Specifications of a typical EV

\begin{tabular}{ll}
\hline Electric vehicle & BMW i3 (AC charging 11 kW) (AC Typ 2 @ \\
& $11 \mathrm{~kW})$ \\
Manufacturer & BMW \\
Range in accordance with WLTP & $359 \mathrm{~km}$ \\
Battery Capacity & $42.2 \mathrm{kWh}$ \\
Consumption (input/ calculated)) & $13.1 / 11.8 \mathrm{kWh} / 100 \mathrm{~km}$ \\
Number of seats & 4 \\
Engine power in & $125 \mathrm{~kW} / 170 \mathrm{PS}$ \\
Desired range per week & $250 \mathrm{~km}$ \\
Time at charging station & $8 \mathrm{~h}$ \\
\hline
\end{tabular}

The following section describes the selection of panel and inverter which are the most important components of the solar PV system.

\section{Selection of PV panels}

The total system capacity to be installed is estimated at $12 \mathrm{kWp}$. The rated power of a $\mathrm{PV}$ panel is $400 \mathrm{~W}$, then the number of panels to be installed is:

$\mathrm{N}_{\mathrm{PV}}=\mathrm{P}_{\mathrm{PV}, \text { required }} / \mathrm{P}_{\text {Array }}=1200 / 400=30$ (panels).

Where, $\mathrm{N}_{\mathrm{PV}}$ : number of solar panels needs to be installed; $\mathrm{P}_{\mathrm{PV}}$, required: power of $\mathrm{PV}$ system needs to be installed (Wp); $\mathrm{P}_{\text {Array }}$ : rated power of solar panel $(\mathrm{Wp})$.

In this project, the selected number of modules is 30 and its model is AE 400HM6-72. The detailed specifications of solar panels are described in Table 4.

TABLE 4. Specifications of PV panel

\begin{tabular}{ll}
\hline Specifications & Values \\
\hline Model & AE 400HM6-72 \\
Manufacturer & AE Solar \\
Nominal max power (Pmax) & $400 \mathrm{Vp}$ \\
Maximum power voltage (Vmp) & $41.45 \mathrm{~V}$ \\
\hline
\end{tabular}




\begin{tabular}{ll}
\hline Maximum power current (Imp) & $9.65 \mathrm{~A}$ \\
Open circuit voltage (Voc) & $49.72 \mathrm{~V}$ \\
Short circuit current (Isc) & $10.44 \mathrm{~A}$ \\
Module efficiency & $20.18 \%$ \\
Maximum system voltage DC & $1000 \mathrm{~V}$ \\
\hline
\end{tabular}

\section{Selection of inverter}

The power of the inverter is selected according to the rule (Mondol et al., 2006; Nguyen \& Hoang, 2021).

$\mathrm{P}_{\text {Inv }}=\mathrm{P}_{\mathrm{PV} \text {, required }} / 1.2=12000 / 1.2=10000(\mathrm{~W})$

Where, $\mathrm{P}_{\text {inv }}$ : the rated power of the inverter; 1.2 is a compatibility coefficient which

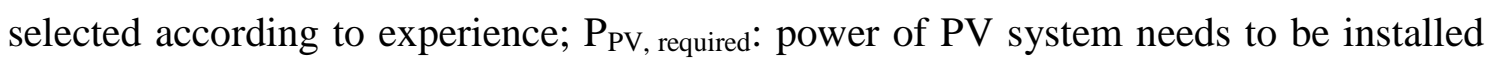
(Wp).

In this project, the power of the inverters selected is $10 \mathrm{kWp}$, its model is ABB PVI10.0-TL OUTD. The detailed specifications of the inverter are described in Table 5.

TABLE 5. Inverter specifications

\begin{tabular}{ll}
\hline Inverter & Specifications \\
\hline Model & ABB PVI-10.0-TL OUTD \\
Manufacturer & ABB \\
Max. DC Power Pmax-DC(W) & $13 \mathrm{~kW}$ \\
MPP(T) Voltage Range Uin (V) & $300 \sim 750 \mathrm{~V}$ \\
Max. DC Voltage Vmax (V) & $900 \mathrm{~V}$ \\
Min. DC Voltage to Start Feed In (V) & $360 \mathrm{~V}$ \\
Max. DC Current Isc (A) & $34 \mathrm{~A}$ \\
Max. AC Power Pmax-AC (W) & $11 \mathrm{~kW}$ \\
Output AC Voltage Range Uout (V) & $320 \sim 480 \mathrm{~V}$ \\
Rated AC Voltage & $400 \mathrm{~V}$ \\
Max. AC Current (Iout-sc) & $16.6 \mathrm{~A}$ \\
Frequency (Hz) & $50,60 \mathrm{~Hz}$ \\
Max. Efficiency (\%) & $97.1 \%$ \\
\hline
\end{tabular}

In this study, the number of panels to be installed is 30 , the inverter has two MPPTs. Therefore, the system is divided into two strings and each string has 15 solar panels attached.

\subsection{Simulation}

In this research, PVSOL software is chosen because it is an easy, fast and reliable software tool for the simulation of solar PV system (Dondariya et al., 2018). The $\mathrm{PV} * \mathrm{SOL}$ software supports system designers in deciding the PV system. The software evaluates the necessary data and calculates the solar yield. The main steps involved in the simulation are given below:

Step 1: Fill in the information of the design; 
Step 2. Choose PV system type and weather;

Step 3: Determine the civil load;

Step 4: Select the electric vehicle type and the parameters of the charging station;

Step 5: Choose the power cord to connect;

Step 7: Run the simulation;

Step 8: Following the simulation, a summary of the project report is given. This report is ready to be printed out.

The single-line diagram of the solar PV system and 3D configuration of PV panels on the PVSOL software are described in Figure 7 and Figure 8.

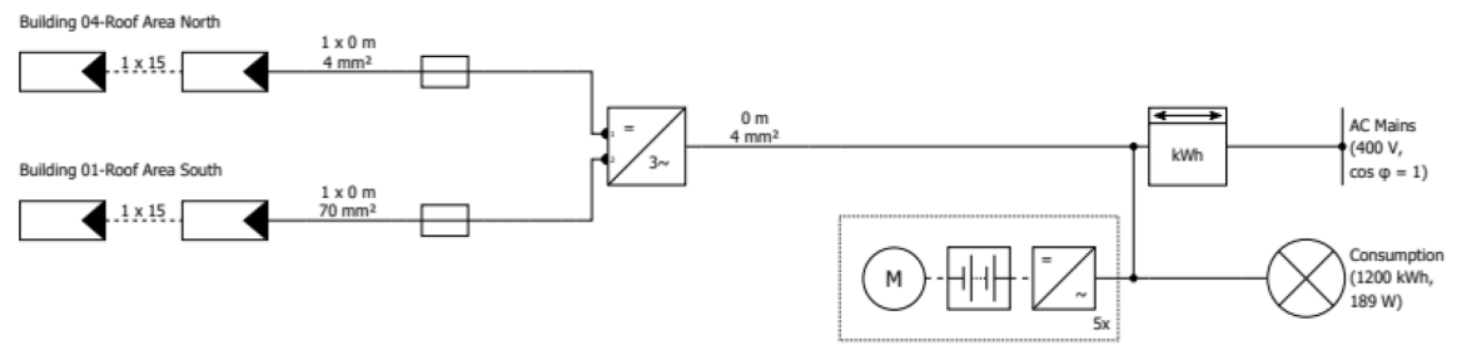

Figure 7. Proposed diagram of PV system connected to grid and EV

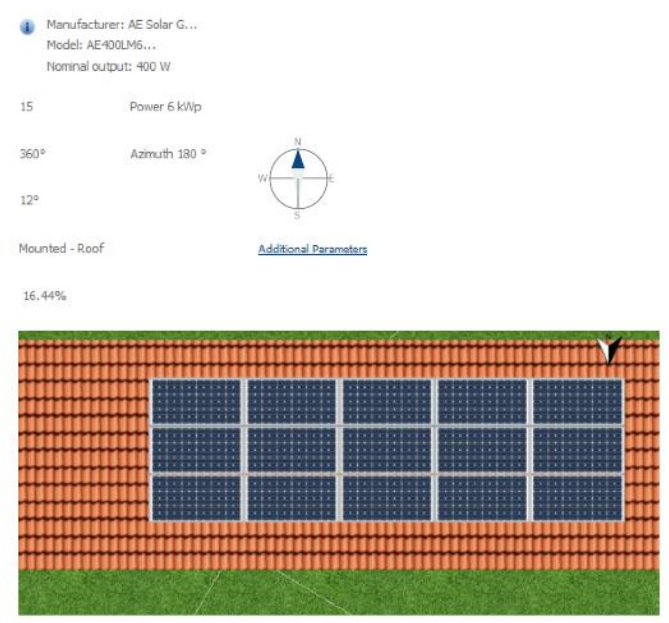

Figure 8. 3D configuration of solar panels on PVSOL software

\section{Results of Simulation}

Figure 9 and Table 6 show the energy flow of the system over a year. The amount of electricity produced from the solar power system is $16,864 \mathrm{kWh}$; the amount of electricity sold to the national grid is $4,087 \mathrm{kWh}$, the amount purchased from the national grid is $597 \mathrm{kWh}$, the amount of electricity supplied to the charging station is 
$12,160 \mathrm{kWh}$ and the efficiency of the system is $78.7 \%$.

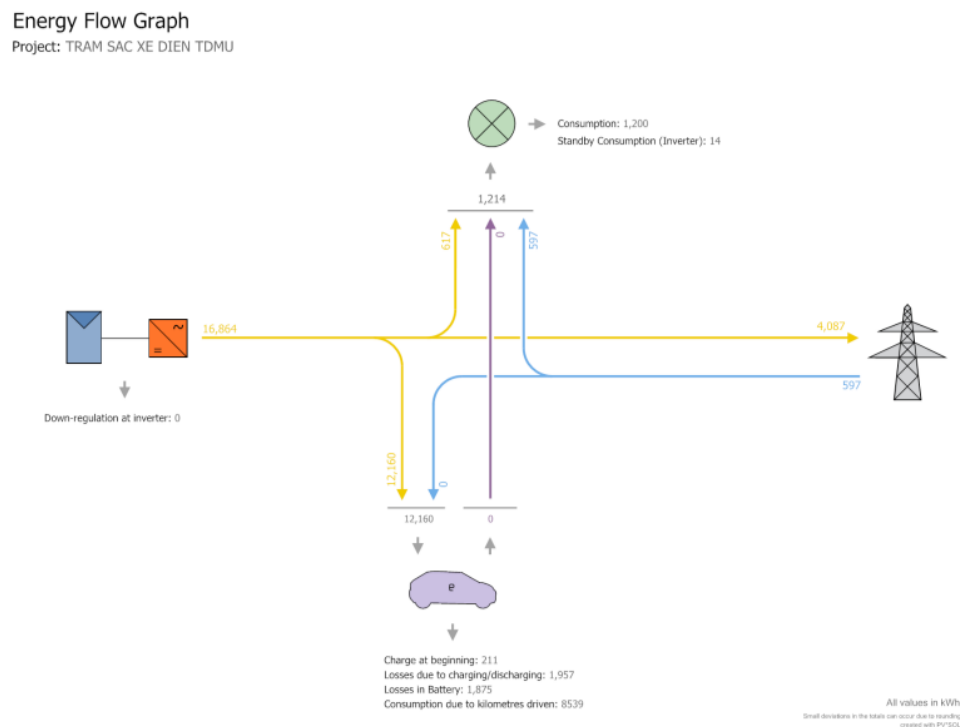

Figure 9. Energy flow graph

TABLE 6. The simulated yield of the PV system

\begin{tabular}{ll}
\hline Parameters & Values \\
\hline PV generator energy ( AC Grid ) & $16,864 \mathrm{kWh} /$ year \\
Spec. annual yield & $1,404.11 \mathrm{kWh} / \mathrm{kWp}$ \\
Performance ratio (PR ) & $78.7 \%$ \\
Grid feed - in & $4,087 \mathrm{kWh} /$ year \\
\hline
\end{tabular}

Figure 10 shows production forecast with monthly consumption. Figure 11 represents the uses of PV energy for grid feeding, electric vehicle charging and own usage. It can be seen from Figure 10 that the PV generation in March is highest. In March, PV generation is $1526.2 \mathrm{kWh}$, electric vehicle charging is $1035.3 \mathrm{kWh}$, grid feeding is $438.2 \mathrm{kWh}$, and the remaining power is for internal use.

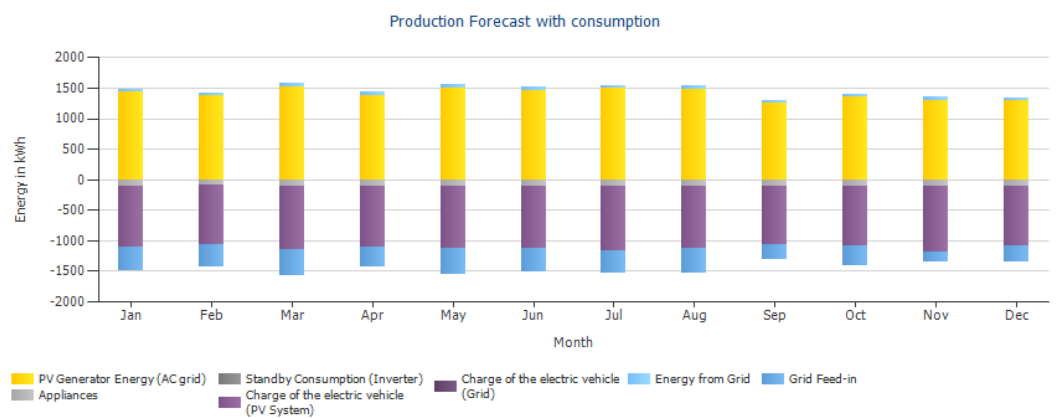

Figure 10. Production forecast with consumption 


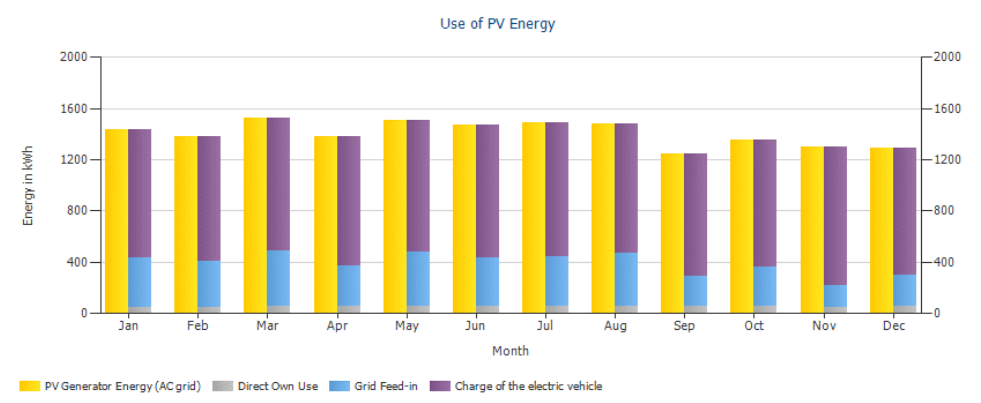

Figure 11. Use of energy

\section{Environmental Impact and Economic Analysis}

\subsection{Environmental impact}

The rooftop solar project not only brings energy benefits but also contributes to reducing $\mathrm{CO} 2$ emissions to the environment. The amount of $\mathrm{CO} 2$ emission reduction of the solar PV within a year simulated by PVSOL software is 7,919 kg. Figure 12 shows the environmental and output parameters of the solar PV system.

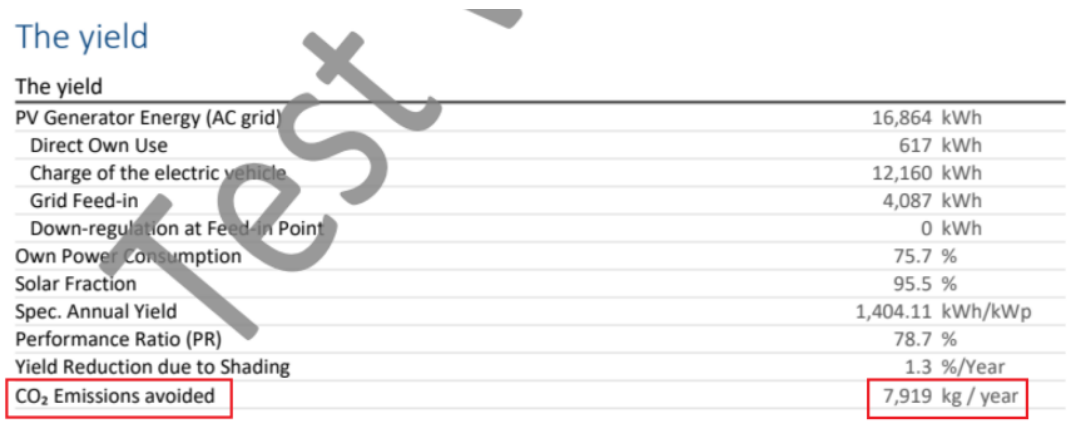

Figure 12. The amount of $\mathrm{CO} 2$ emission reduction of the solar $P V$ in a year

\subsection{Economic analysis}

This section describes the calculation of the initial investment cost of the solar PV system, profitability and simple payback period. The initial investment cost which is calculated based on the market price and the structure of the designed solar PV system is described in Table 7. The lifetime of the PV system is estimated to be 20 years. The electricity bought from Vietnam Electricity Group (EVN) is calculated at the price for administrative units which is $1,659 \mathrm{VND} / \mathrm{kWh}$ (EVN., 2021). The residual electricity is sold back to EVN at the price of 1,943 VND/ kWh (Table 8) (The Prime Minister, 2020).

TABLE 7. Initial investment for the proposed solar PV system

\begin{tabular}{ll}
\hline Items & Price (VND) \\
\hline
\end{tabular}




\begin{tabular}{ll}
\hline Solar Panel 400Wp & $109,500,000$ \\
Inverter ABB PVI-10.0-TL-OUTD & $57,602,000$ \\
Other equipment & $120,915,500$ \\
Installation cost & $10,000,000$ \\
Total initial cost & $298,017,500$ \\
\hline
\end{tabular}

$T A B L E$ 8. Feed-in tariff for solar power

\begin{tabular}{clcc}
\hline \multirow{2}{*}{ No. } & \multirow{2}{*}{ Rooftop solar power project } & \multicolumn{2}{c}{ Feed-in Tariff } \\
\cline { 3 - 4 } & & $\mathbf{V N D / k W h}$ & Equivalent to UScent/kWh \\
\hline 1 & Floating solar power project & 1,783 & 7,69 \\
2 & Ground mounted solar power project & 1,644 & 7,09 \\
3 & Rooftop solar power project & 1,943 & 8,38 \\
\hline
\end{tabular}

(Note: The applicable exchange rate between VND and USD is the central exchange rate published by the State Bank of Viet Nam on 10th March 2020)

TABLE 9. Economic benefits of the PV system.

\begin{tabular}{|c|c|c|c|c|c|c|c|c|}
\hline \multicolumn{3}{|c|}{ Without PV system } & \multicolumn{4}{|c|}{ With PV system } & \multirow[b]{2}{*}{$\begin{array}{l}\text { Profit/year } \\
(1000 \\
\text { VND) }\end{array}$} & \multirow{2}{*}{$\begin{array}{l}\text { Simple } \\
\text { payback } \\
\text { period } \\
\text { (years) }\end{array}$} \\
\hline $\begin{array}{l}\text { Energy } \\
\text { from } \\
\text { grid } \\
(\mathrm{kWh})\end{array}$ & $\begin{array}{l}\text { Payment } \\
\text { to EVN } \\
(1000 \\
\text { VND) }\end{array}$ & $\begin{array}{l}\text { PV } \\
\text { generator } \\
\text { energy } \\
(\mathrm{kWh})\end{array}$ & $\begin{array}{l}\text { Energy } \\
\text { from } \\
\text { grid } \\
(\mathrm{kWh})\end{array}$ & $\begin{array}{l}\text { Payment } \\
\text { to EVN } \\
(1000 \\
\text { VND }\end{array}$ & $\begin{array}{l}\text { Grid } \\
\text { feed-in } \\
(\mathrm{kWh})\end{array}$ & $\begin{array}{l}\text { Money } \\
\text { from } \\
\text { selling } \\
\text { (VND) }\end{array}$ & & \\
\hline 13,374 & $22,187.47$ & 16863.8 & 597 & 990.42 & 4087.2 & $7,941.4$ & $29,138.45$ & 10.23 \\
\hline
\end{tabular}

Table 9 describes benefits of the PV system. If there is no solar power system, the annual load is $13,374 \mathrm{kWh}$, the corresponding amount to be paid is $22,187,466.00$ VND. When the solar power system is installed, the amount of electricity purchased from EVN is $597 \mathrm{kWh}$, thus reducing the annual amount to be paid to EVN by $21,197,050.0$ VND. In addition, the system can also sell the unused amount of solar energy to the grid according to Circular 13 which is equivalent to 7,941,429.60 VND. Thus, the total profit earned in the first year is $29,138,450$ VND.

\section{Conclusion}

The study is carried out to determine the energy, environmental impact and economic parameters of the PV system for EV charging based on simulation. The rooftop PV systems are now increasingly installed. Through simulations, the obtained energy is $16,864 \mathrm{kWh} /$ year, the annual specific yield in $\mathrm{kWp}$ is $1,404.11 \mathrm{kWh}$ and the avoided $\mathrm{CO} 2$ emission is $7,919 \mathrm{~kg} /$ year. However, economic problems still exist, making investment efficiency low because of the payback period is so long. Currently, the Vietnamese government is offering a relatively high price for purchasing electricity generated from rooftop solar power projects, nevertheless it is forecasted that the price will be lower in the coming years, making the payback period longer and reduces the economic values of the project. 
To conclude, from financial aspect, this project is not very efficient, however, the project is feasible in terms of energy production.

\section{Acknowledgement}

The authors would like to acknowledge Thu Dau Mot University in Vietnam for its support.

\section{References}

A. K. Karmaker, M. R. Ahmed, M. A. Hossain, and M. M. Sikder (2018). Feasibility assessment \& design of hybrid renewable energy based electric vehicle charging station in Bangladesh. Sustain. Cities Soc., vol. 39, 189-202, doi: 10.1016/j.scs.2018.02.035.

C. Dondariya et al., (2018). Performance simulation of grid-connected rooftop solar PV system for small households: A case study of Ujjain, India. Energy Reports, vol. 4, pp. 546-553, doi: 10.1016/j.egyr.2018.08.002.

D. Larcher and J. M. Tarascon (2015). Towards greener and more sustainable batteries for electrical energy storage. Nature Chemistry, 7(1), 19-29. Nature Publishing Group. doi: 10.1038/nchem.2085.

D. Nong, C. Wang, and A. Q. Al-Amin (2020). A critical review of energy resources, policies and scientific studies towards a cleaner and more sustainable economy in Vietnam, Renew. Sustain. Energy Rev., vol. 134, p. 110117, 2020, doi: 10.1016/j.rser.2020.110117.

EVN (2021). Electricity Retail Price of Vietnam 2021. https://www.evn.com.vn/c3/evn-vakhach-hang/Bieu-gia-ban-le-dien-9-79.aspx (accessed Mar. 12, 2021).

G. R. Chandra Mouli, P. Bauer, and M. Zeman (2016). System design for a solar powered electric vehicle charging station for workplaces. Appl. Energy, vol. 168, pp. 434-443, doi: 10.1016/j.apenergy.2016.01.110.

G. R. Chandra Mouli, P. Bauer, and M. Zeman (2016). System design for a solar powered electric vehicle charging station for workplaces. Appl. Energy, vol. 168, pp. 434-443, doi: 10.1016/j.apenergy.2016.01.110.

Government of Vietnam (2015). Vietnam Renewable Energy Development Strategy 2016-2030 with outlook until 2050, Policies - IEA, 2015. https://www.iea.org/policies/6095-vietnamrenewable-energy-development-strategy-2016-2030-with-outlook-until-2050-reds (accessed Mar. 15, 2021).

H. Kimura, Shigeru \& Phoumin (2019). Energy Outlook and Energy Saving Potential in East Asia 2019. Think Asia, https://think-asia.org/handle/11540/9786 (accessed Mar. 12, 2021).

H. N. D. Nguyễn (2017). Tính toán thiết kế hệ thống năng lượng mặt trời sử dụng cho trạm sạc xe điện. Trường Đại học Bách khoa - Đại học Đà Nẵng. Accessed: Mar. 12, 2021. http://tainguyenso.dut.udn.vn/handle/DUT/338.

H. P. Nguyen, A. T. Hoang, A. T. Le, V. V. Pham, and V. N. Tran (2020). Learned experiences from the policy and roadmap of advanced countries for the strategic orientation to electric 
vehicles: A case study in Vietnam. Energy Sources, Part A Recover. Util. Environ. Eff., doi: 10.1080/15567036.2020.1811432.

H. S. Das, M. M. Rahman, S. Li, and C. W. Tan (2020). Electric vehicles standards, charging infrastructure, and impact on grid integration: A technological review. Renew. Sustain. Energy Rev., vol. 120, doi: 10.1016/j.rser.2019.109618.

IMF. (2019). World Economic Outlook, October 2019: Global Manufacturing Downturn, Rising Trade Barriers. International Monetary Fund. https://www.imf.org/en/Publications/WEO/Issues/2019/10/21/World-Economic-OutlookOctober-2019-Global-Manufacturing-Downturn-Rising-Trade-Barriers-48513 (accessed Mar. 12, 2021).

J. A. Domínguez-Navarro, R. Dufo-López, J. M. Yusta-Loyo, J. S. Artal-Sevil, and J. L. BernalAgustín (2018). Design of an electric vehicle fast-charging station with integration of renewable energy and storage systems. Int. J. Electr. Power Energy Syst., vol. 105, 46-58. doi: 10.1016/j.ijepes.2018.08.001.

J. D. Mondol, Y. G. Yohanis, and B. Norton (2006). Optimal sizing of array and inverter for grid-connected photovoltaic systems. Sol. Energy, 80(12), 1517-1539, doi: 10.1016/j.solener.2006.01.006.

J. Polo et al., (2015). Solar resources and power potential mapping in Vietnam using satellitederived and GIS-based information. Energy Convers. Manag., vol. 98, pp. 348-358, doi: 10.1016/j.enconman.2015.04.016.

L. D. Le Nguyen et al. (2019). Facade Integrated Photovoltaic Systems: Potential Applications for Commercial Building in Vietnam. In Proceedings of 2019 International Conference on System Science and Engineering, ICSSE 2019, pp. 219-223, doi: 10.1109/ICSSE.2019.8823134.

M. A. Green (2019). How Did Solar Cells Get So Cheap? Joule, 3(3), 631-633. Cell Press. doi: 10.1016/j.joule.2019.02.010.

M. Pushpavalli, P. Abirami, P. Sivagami, and V. Geetha (2021). Investigation of Grid Connected PV System with Electrial Appliances, Electric Vehicles and Battery Systems using PVsol Software. EAI Endorsed Trans. Energy Web, vol. 4, doi: 10.4108/eai.16-52020.2304108 .

O. Ekren, C. Hakan Canbaz, and Ç. B. Güvel (2021). Sizing of a solar-wind hybrid electric vehicle charging station by using HOMER software. J. Clean. Prod., vol. 279, p. 123615. doi: 10.1016/j.jclepro.2020.123615.

P. Software, "PV*SOL premium - Valentin Software GmbH," Valentin Software GmbH, 2021. https://valentin-software.com/en/products/pvsol-premium/ (accessed Mar. 12, 2021).

PVGIS data, "Photovoltaic Geographical Information System (PVGIS) - European Commission," European Commission, 2021. https://re.jrc.ec.europa.eu/pvg_tools/en/tools.html (accessed Mar. 12, 2021).

S. Bellekom, R. Benders, S. Pelgröm, and H. Moll (2012). Electric cars and wind energy: Two problems, one solution? A study to combine wind energy and electric cars in 2020 in The Netherlands. Energy, 45(1), 859-866, doi: 10.1016/j.energy.2012.07.003.

S. F. Tie and C. W. Tan (2013). A review of energy sources and energy management system in electric vehicles. Renewable and Sustainable Energy Reviews, vol. 20. Pergamon, pp. 82-102, doi: 10.1016/j.rser.2012.11.077. 
S. IEC. (2014). Plugs, Socket-outlets and Couplers for industrial and similar applications, and for Electric Vehicles - Part 1, 2, 3. IEC, https://www.iec.ch/dyn/www/f?p=103:23:0::::FSP_ORG_ID:1426 (accessed Mar. 07, 2021).

S. S. J1772, “J1772: SAE Electric Vehicle and Plug in Hybrid Electric Vehicle Conductive Charge Coupler - SAE International," SAE International, 2012. https://www.sae.org/standards/content/j1772_201210/(accessed Mar. 07, 2021).

Thanh Ba Nguyen, Phuong Van Hoang (2021). Design, Simulation and Economic Analysis of A Rooftop Solar PV System in Vietnam. EAI Endorsed Trans. Energy Web, p. 168504, 2021, doi: 10.4108/eai.27-1-2021.168504.

The Prime Minister (2015). Decision of the Prime Minister No. 2068/QD-TTG of 2015 on Development Strategy of Renewable Energy of Vietnam by 2030 with a Vision to 2050. Decision date November $25^{\text {th }}, 2015$.

The Prime Minister (2017). No. 11/2017/QD-TTg,| ESCAP Policy Documents Management. The Prime Minister of the Socialist Republic of Vietnam, date April 11, 2017. https://policy.asiapacificenergy.org/node/3447 (accessed Mar. 12, 2021).

The Prime Minister (2020). Mechanisms to Promote the Development of Solar Power Projects in Viet Nam. Decision No. 13/2020/QD-TTg. https://policy.asiapacificenergy.org/node/4056 (accessed Mar. 12, 2021).

W. A. Salah et al., (2019). Electric vehicle technology impacts on energy. Int. J. Power Electron. Drive Syst., 10(1), 1, doi: 10.11591/ijpeds.v10.i1.pp1-9. 